\title{
TWO-DIMENSIONAL SIMULATION OF NON-NEWTONIAN FLOW
}

\author{
ANDRÉS V. PÉREZ ${ }^{1 *}$, REYNA HUANCARA ${ }^{1}$, FLOR CUTIRE $^{1}$, NATALY PEREZ $^{2}$ \& ANAI PEREZ ${ }^{3}$ \\ ${ }^{1}$ School of Civil Engineering, National University of Saint Agustin, Peru \\ ${ }^{2}$ Pratt School of Engineering, Duke University, USA \\ ${ }^{3}$ Graduate School of Architecture, Planning and Preservation, Colombia University, USA
}

\begin{abstract}
Every year in the south of Peru, rainy seasons produce mud flow along a river in the Andes Mountains, causing flooding in the Pescadores Valley, as well as the Panamericana Highway, paralyzing vehicular traffic along southern Peru's main road. The flooding is of a non-Newtonian flow comprised of torrential rainwater, stones and sediments, this flow will be simulated in the Pescadores valley in order to avoid annual flooding and to propose channeling the river with an embankment dam and a bridge over the Panamericana Highway. For the two-dimensional computational simulation, the hydrological design of the basin was made from the maximum rainfall of 24 hours, until the hydrograph of maximum design flows was obtained, considering a return period that will be based on the expected life of the structure and a percentage of the risk of failure. In addition, a study of soil mechanics was conducted in order to determine the rheological parameters of the flow, as well as a topographic survey in the field with a drone system. With the following information the flow was simulated using the rheological, quadratic and two-dimensional models, as well as numerically solving the continuity equations and quantity of non-Newtonian flow movement (mud flooding). Once the calibration was done, the design of the channelling of the river with an embankment dam and a concrete bridge over the road was proposed.
\end{abstract}

Keywords: two-dimensional simulation, mud flooding, hazard map, Peru.

\section{INTRODUCTION}

Due to global warming, the climate in many regions of Peru has been drastically changing. This study evaluated the intense rainfall that occurs during the summer season throughout the Peruvian mountain range, which cause destructive events known as mud flooding.

Mud flooding are non-Newtonian flows which cannot be studied by river hydraulics making it necessary to use a rheological model. On the other hand, the Pescadores Valley presents an urban topography, therefore, to obtain an accurate model it is indispensable the use of a two-dimensional numerical model. In order to do this, topographic, geotechnical and hydrological studies of the area were first carried out, in order to know the characteristics of the basin that will serve as data in the simulation. Finally, a solution to the interruption of vehicular traffic and the flooding of the valley is proposed.

\section{PROBLEMATIC}

In 2017, due to the hydrological phenomenon of El Niño in Peru, mudflows and floods were produced that destroyed hundreds of kilometers of roads and more than 200 bridges, leaving entire villages isolated and causing the deaths of more than 100 people, causing an economic damage of more than US $\$ 3,000$ million in damages [1].

The intersection of the Panamericana Highway South at km $756+400$, which crosses the Pescadores Valley, is frequently affected by sludge avenues, causing frequent blockages, uncommunicated cities, and affecting crops and settlers (Fig. 1).

* ORCID: https://orcid.org/0000-0002-3404-4349 


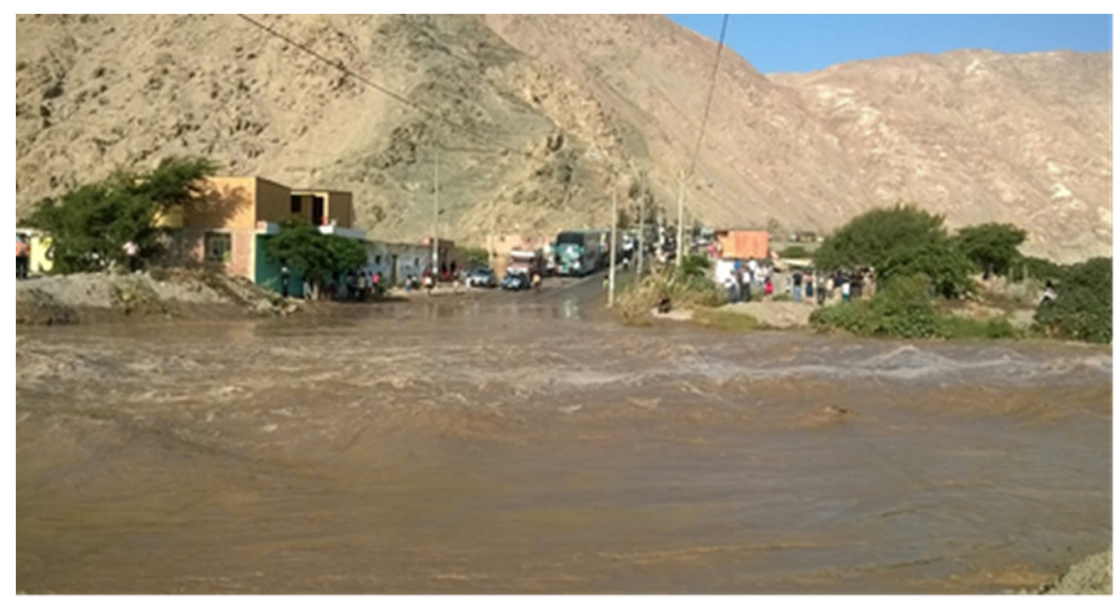

Figure 1: Panamericana South Highway km $756+400$, traffic interrupted by mud flooding.

\section{GOVERNING EQUATIONS}

Hydraulics studies Newtonian flows, that is, liquids such as water; however, sludge flows are non-Newtonian flows that are analyzed by rheology.

It is a non-Newtonian flow when the relation between the magnitude of the applied shear stress and the variation of deformation is nonlinear [2].

Mud flow is the mixture of sediments and water in a proportion between $20 \%$ and $60 \%$ that flows through a channel; in Peru the mud flow is known as "huaicos" [3].

To analyze, formulate, and solve this phenomenon it is necessary to solve the dynamic wave equation in two dimensions. These events present cones of dejection in the valleys, so it is necessary to consider a two-dimensional mathematical model.

In order to properly choose the mathematical model, it is necessary to know the characteristics that the event to simulate presents; therefore, it was decided to use the twodimensional model that simulates mudflows.

The two-dimensional governing equations [4] correspond to the continuity equations, and these present a numerical solution

$$
\frac{\partial h}{\partial t}+\frac{\partial(h u)}{\partial x}+\frac{\partial(h v)}{\partial y}=i
$$

where:

$h$ is the depth of mud flow;

$u$ and $v$ are the velocities of the mud flow in $\mathrm{x}$ and $\mathrm{y}$ directions respectively;

$t$ is time; and

$i$ is the intensity of precipitation.

The equation of quantity of movement is expressed as follows

$$
\begin{gathered}
S_{f_{x}}=S_{0 x}-\frac{\partial h}{\partial x}-\frac{u}{g} \frac{\partial u}{\partial x}-\frac{v}{g} \frac{\partial u}{\partial y}-\frac{1}{g} \frac{\partial u}{\partial t}, \\
S_{f_{y}}=S_{0 y}-\frac{\partial h}{\partial y}-\frac{v}{g} \frac{\partial v}{\partial y}-\frac{u}{g} \frac{\partial v}{\partial x}-\frac{1}{g} \frac{\partial v}{\partial t}
\end{gathered}
$$


where:

$g$ is the acceleration of gravity;

$S_{f x}$ is the slope of friction; and

$S_{0 x}$ is the slope of channel.

Non-Newtonian tangential efforts are expressed with the rheological quadratic model, presented by O'Brien and Julien in 1985 [5]

$$
\tau=\tau_{y}+\eta \frac{\partial u}{\partial y}+C_{1}\left(\frac{\partial u}{\partial y}\right)^{2},
$$

where:

$\tau_{y}$ is the shear stress;

$\eta$ is the dynamic viscosity;

$\frac{\partial u}{\partial y}$ is the velocity gradient; and

$C_{1}$ is the dispersive turbulent parameter.

The procedure for obtaining the dispersive turbulent parameter $C_{1}$, is the following

$$
C_{1}=\rho_{m} l^{2}+f\left(\rho_{m}, C_{v}\right) d_{s}^{2} .
$$

In these equations, $\eta$ is the dynamic viscosity; $\tau_{c}$ is the cohesive yield stress, $\tau_{m c}$ is the Mohr Coulomb stress which depends on the intergranular pressure (ps), and the angle of repose $(\varphi)$ of the material; $C_{1}$ denotes the initial shear stress coefficient, which depends on the mass density of the mixture $\rho_{m}$, the Prandtl $l$ mixture length, the size of the sediment ds and a function of the volumetric concentration of sediments $C_{v}$. Bagnold [6] defined the function

$$
f\left(\rho_{m}, C_{v}\right)=a_{i} \rho_{m}\left[\left(\frac{C *}{C_{v}}\right)^{1 / 3}-1\right]
$$

where:

$a_{i}$ is the empirical coefficient $(\sim 0.01)$; and

$C *$ is the maximum static volume concentration of sediment particles.

\subsection{Numerical solution of the FLO-2D model}

The shear stress in hyperconcentrated sediment flows can be determined by the sum of the five shear stress components. The total shear stress $\tau$ depends on the cohesive yield stress $\tau_{c}$, the Mohr-Coulomb stress $\tau_{m c}$, the viscous stress $\tau_{v}(\eta d v / d y)$, the turbulent stress $\tau_{t}$ and the dispersive stress $\tau_{d}$

$$
\tau=\tau_{c}+\tau_{m c}+\tau_{v}+\tau_{t}+\tau_{d}
$$

where:

$$
\tau_{y}=\tau_{c}+\tau_{m c}
$$

To define all the shear stress terms used by the FLO-2D model, the shear stress ratio is integrated in depth and is rewritten as a dimensionless slope as follows:

$$
S_{f}=S_{y}+S_{v}+S_{t d}
$$


where:

$S_{f}$ : slope of friction;

$S_{y}:$ slope of creep;

$S_{v}$ : viscous slope; and

$S_{t d}:$ turbulent-dispersed slope.

The viscous slope and the turbulent-dispersed slope are written in terms of depth-averaged velocity $V$. The viscous slope can be written as:

$$
S_{v}=\frac{K \eta}{8 \gamma_{m}} \frac{V}{h^{2}}
$$

where:

$\gamma_{m}:$ specific weight of the sediment mixture; and

$K$ : laminar flow resistance parameter.

The flow resistance $n_{t d}$ of the components of the turbulent and dispersive shear stress are combined as an equivalent Manning value $\mathrm{n}$ for the flow:

$$
S_{t d}=\frac{n_{t d}^{2} V^{2}}{h^{4 / 3}}
$$

At very high concentrations, the dispersive stress reached by the contact of the sediment particles increases the flow resistance $n_{t d}$ by the transfer of impulse flow to the boundaries. To estimate this increase in flow resistance, the conventional turbulent resistance flow $n_{t}$ is increased by an exponential function of the sediment concentration $C_{v}\left(\mathrm{O}^{\prime}\right.$ Brien and Julien [5])

$$
n_{t d}=n_{t} b e^{m c_{v}},
$$

where $b$ is a coefficient (0.0538) and $m$ an exponent (6.0896).

The components of the friction slopes are then combined in the following way:

$$
S_{f}=\frac{\tau_{y}}{\gamma_{m} h}+\frac{K \eta V}{8 \gamma_{m} h^{2}}+\frac{\eta_{t V^{2}}^{2}}{h^{4} / 3} .
$$

FLO 2D provides a solution with the finite difference method, using an explicit scheme. For the numerical stability of the calculations, uses the Courant-Friedrich-Lewy condition.

The FLO-2D model will solve the equation of momentum to calculate velocity.

\subsection{Grid characteristics}

This model uses a quadrangular structured grid. The topography of the surface is discretized in a grid formed by cells or square elements of uniform size for the entire study area and each element is assigned a position in the grid, an elevation or ground level and a roughness coefficient $\mathrm{n}$ of Manning.

The grid cell size should reflect the level of detail of the topographic data, for which a balance should be sought between the grid cell size and the time it takes for the computer to simulate with that cell size.

The cell size used in the present study was $3.00 \mathrm{~m}$, with a resulting number of cells of 353,065 . 


\section{BASIC STUDIES FOR THE SIMULATION}

\subsection{Topography}

After conducting a previous field survey, the topography survey of the dejection cone of the valley called Los Pescadores was carried out using an eBee RTK drone from a geodetic point provided by the Geophysical Institute of Peru [7] in the Datum system Reference: World Geodetic System (WGS-1984) with Universal Transversal Mercator Cartographic Projection (UTM). Contours were obtained every meter.

Additionally, the differential Global Position System was used to locate and materialize the control points.

\subsection{Hydrology}

The hydrograph was obtained from maximum 24-hour rainfall data due to that these records were the only ones available. The hydrological model HEC-HMS and the Soil Conservation Service (SCS) methodology were used to determine the hydrograph. The 24-hour maximum rainfall records were obtained from the National System of Meteorology and Hydrology of Peru [8]. The net precipitation rate was obtained through the curve number. Then the histogram was transformed into a hydrograph using the unit hydrograph method. The hydrograph is shown in Fig. 2.

The parameters of the HEC-HMS model that were used are those shown in Table 1.

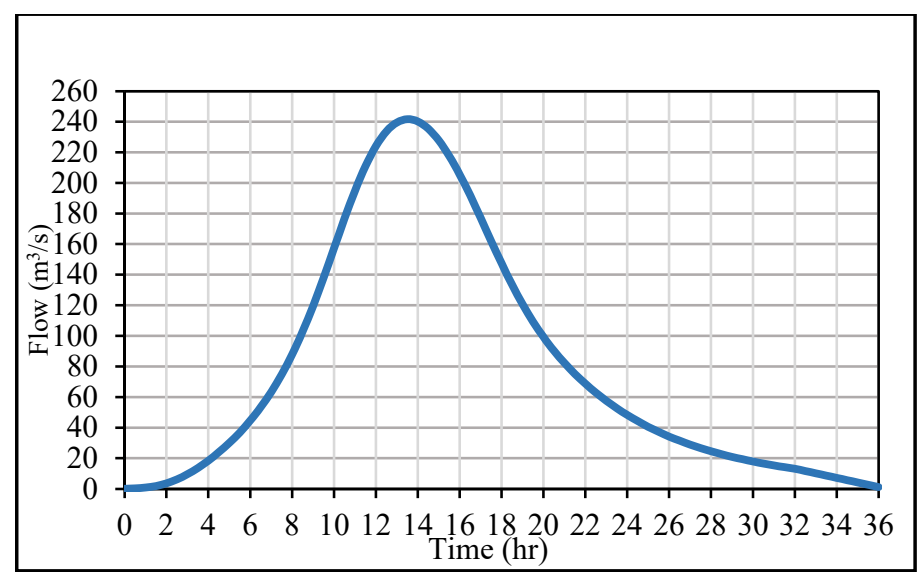

Figure 2: Hydrogram for 200-year return time.

Table 1: Parameters of the model HEC-HMS.

\begin{tabular}{|l|l|}
\hline Area $\left(\mathrm{km}^{2}\right)$ & 1954.90 \\
\hline Loss method & SCS curve number \\
\hline Transform method & SCS unit hydrograph \\
\hline Baseflow method & None \\
\hline Routing method & Muskingum \\
\hline Curve number & 81.70 \\
\hline Lag time (min) & $1,483.00$ \\
\hline
\end{tabular}




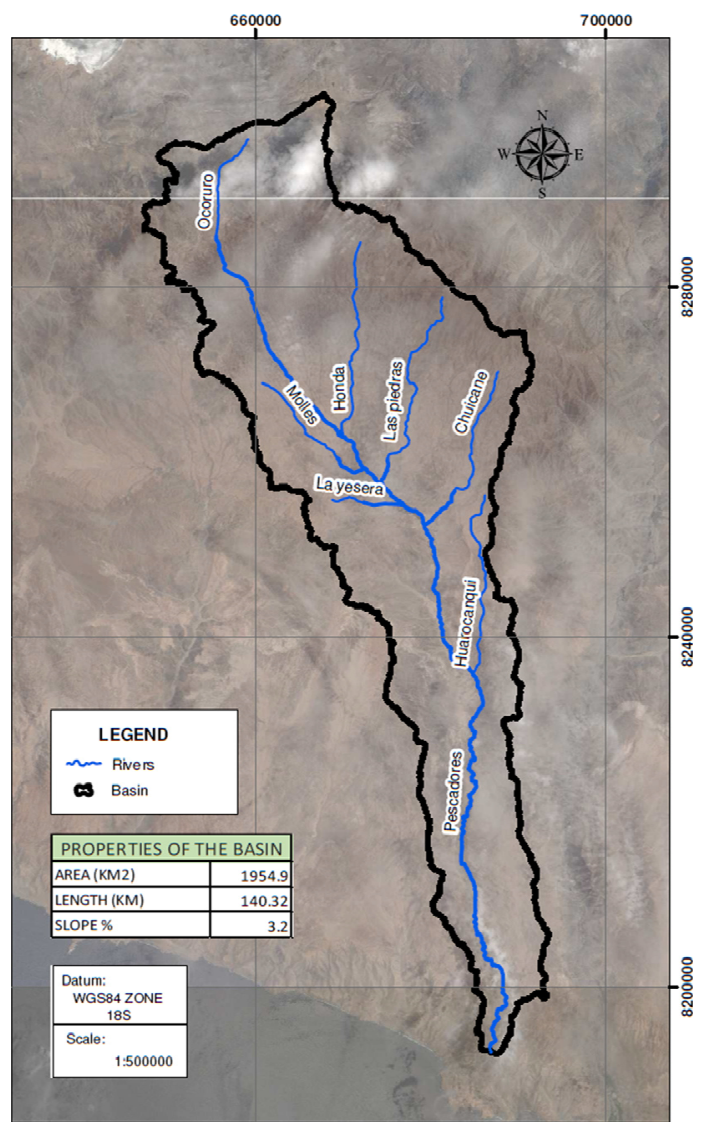

Figure 3: Caravelí - Pescadores hydrological watershed.

Finally, the hydrograph transit was performed using the Muskingum-Cunge method. Fig. 3 shows the study watershed. It was determined that the maximum water flow for a return period of 200 years is $240 \mathrm{~m}^{3} / \mathrm{s}$.

\subsection{Soil mechanics}

Soil samples were taken in different locations of the Pescadores Valley and the riverbed, in order to determine the rheological parameters for the mud flow. The sample that best represented the flow behavior was taken at the beginning of the ejection cone. The soil classification tests determined that the sample corresponds to a sand and silt of low plasticity.

\subsection{Rheological parameters}

The values of rheological parameters such as viscosity and initial stress were calculated. These values were determined by comparing samples collected in situ with "type" samples proposed by O'Brien and Julien in 1988 [9].

After analyzing the samples it was concluded that the sample collected in situ corresponds to the type "Glenwood 3" (Fig. 4). 

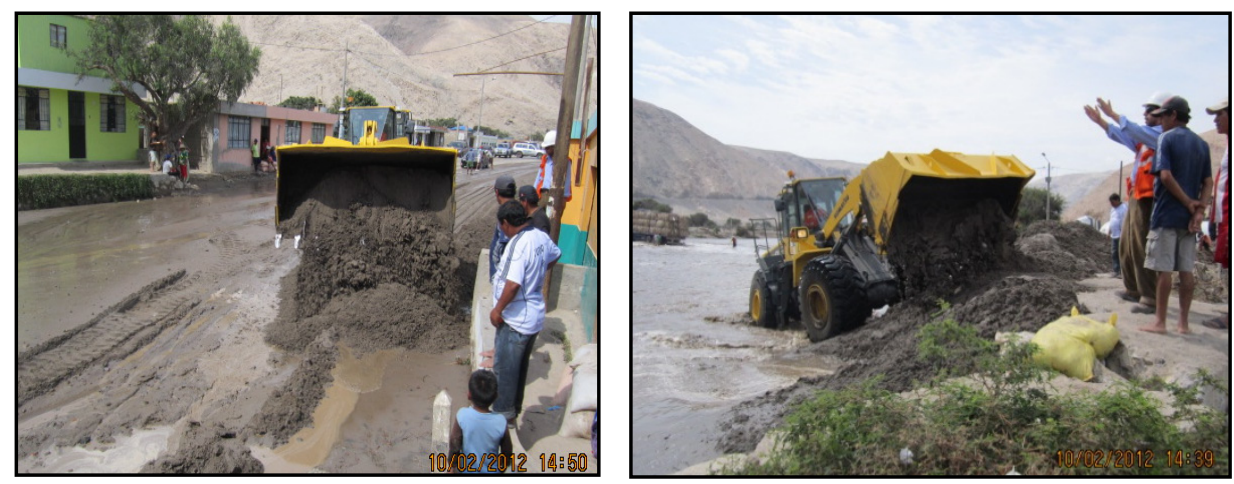

Figure 4: Cleaning of material with front loader and tractor, occurred on 12 February 2012 $(2: 50 \mathrm{pm})[10]$.

The parameters mentioned above, according to their type of classification, are expressed according to the concentration of sediments. Those expressions are described below:

$$
\begin{aligned}
\eta & =0.00632 e 19.9 C v, \\
\tau_{y} & =0.000707 e 29.8 C v .
\end{aligned}
$$

In the present study, the volumetric concentration $(\mathrm{Cv})$ is 0.35 , after the calibration of the model.

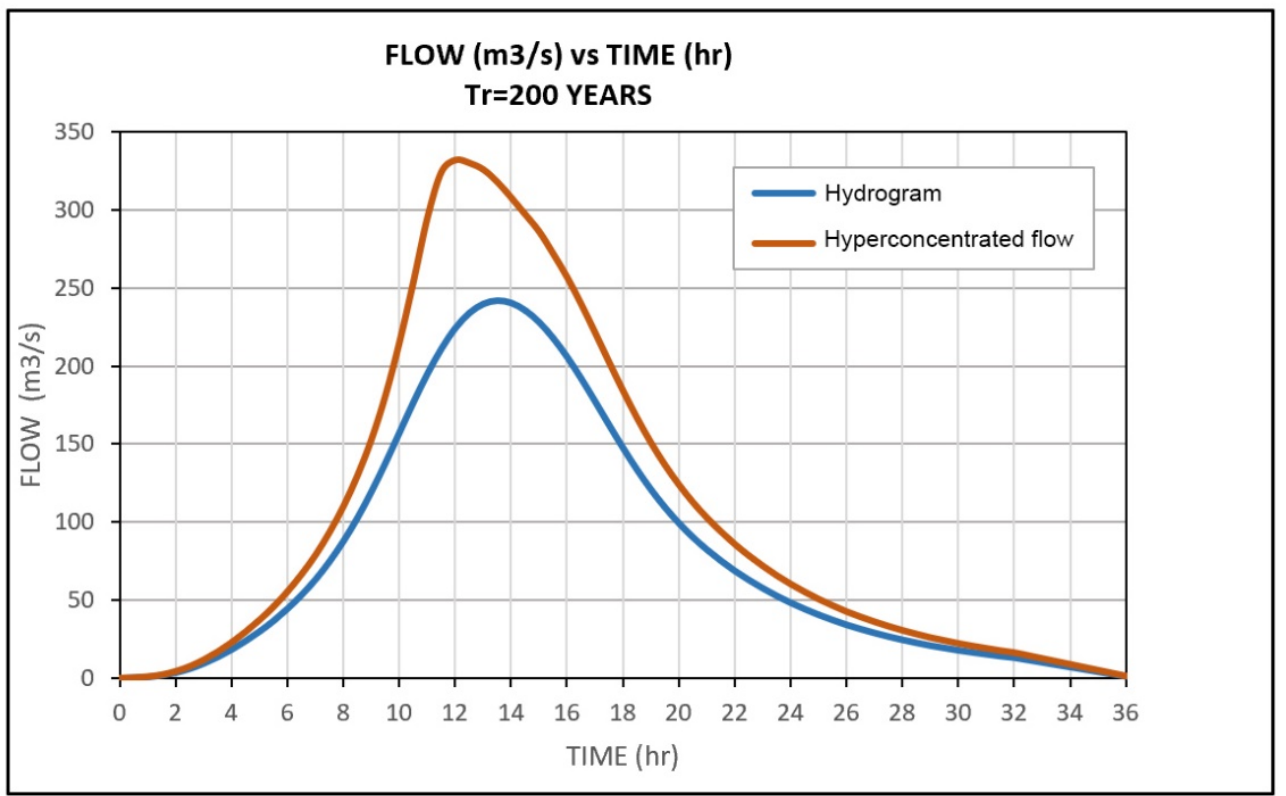

Figure 5: Hydrogram of hyper concentrated flow for a return period of 200 years. 


\section{MUD FLOODING SIMULATION}

The information obtained from the field, such as the topography, hydrology, roughness of the riverbed and soil study, were the input data to FLO 2D which simulated mud flooding. The total hydrograph of water plus mud was also calculated since it is also used for the simulation. It can be seen in Fig. 5.

\subsection{Calibration of the model}

The calibration of the simulation was performed using the maximum precipitation event recorded on 12 February 2012, of which records and audiovisuals are available [11], [12].

For the calibration of the model the estimated in situ flow brace was compared with the brace reported by the model, this approximation was obtained by varying the sediment concentration parameter. The result of this process is shown in Fig. 6.

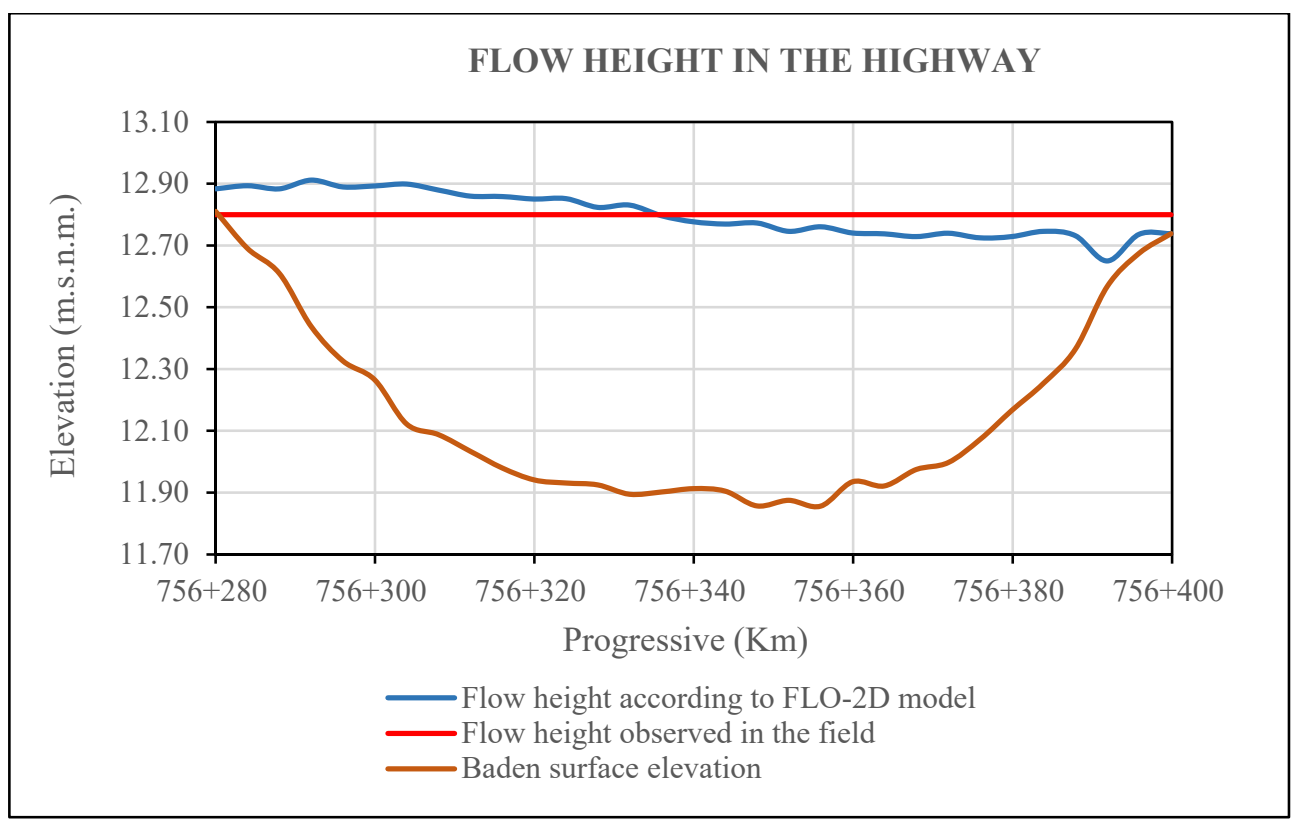

Figure 6: Comparison between flow observed in situ and simulated after calibration.

In Fig. 6, the corresponding profile is shown to the intersection of the highway with the river, the flow level according to the FLO-2D model is calibrated with respect to the flow level observed in the field.

The event that occurred on 12 February 2012, reached a span of $1.00 \mathrm{~m}$ in the center of the ditch, with this value the FLO-2D model was calibrated.

After many iterations it was determined that the sediment concentration is 0.35 , according to that value it is classified as a "mud avenue".

Finally, it was determined that the peak flow of the mud flow hydrograph is $332 \mathrm{~m}^{3} / \mathrm{s}$ as can be seen in Fig. 5 . 


\section{RESULTS}

\subsection{Hazard map}

The methodology that was followed to graph the hazard map of the Pescadores Valley for urban planning was the one proposed by Garcia et al. [13], this method makes a distinction between water flow and mud flow.

Likewise, this methodology establishes the flow intensity, in terms of the product of maximum flow height $\mathrm{h}(\mathrm{m})$ and maximum speed $\mathrm{v}\left(\mathrm{m}^{3} / \mathrm{s}\right)$ which are shown in Table 2 .

Table 2: Intensity level of hazard in mud flows.

\begin{tabular}{|l|c|c|}
\hline Intensity level & Flow height $\mathrm{h}(\mathrm{m})$ & $\begin{array}{c}\text { Product of maximum flow height } \mathrm{h} \text { and } \\
\text { maximum speed } \mathrm{v}\left(\mathrm{m}^{2} / \mathrm{s}\right)\end{array}$ \\
\hline High & $\mathrm{h}>1.00 \mathrm{~m}$ & $\mathrm{vh}>1.00 \mathrm{~m}^{2} / \mathrm{s}$ \\
\hline Medium & $0.20 \mathrm{~m}<\mathrm{h}<1.00 \mathrm{~m}$ & $0.20 \mathrm{~m}^{2} / \mathrm{s}<\mathrm{vh}<1.00 \mathrm{~m}^{2} / \mathrm{s}$ \\
\hline Low & $0.20 \mathrm{~m}<\mathrm{h}<1.00 \mathrm{~m}$ & $\mathrm{vh}<0.20 \mathrm{~m}^{2} / \mathrm{s}$ \\
\hline
\end{tabular}

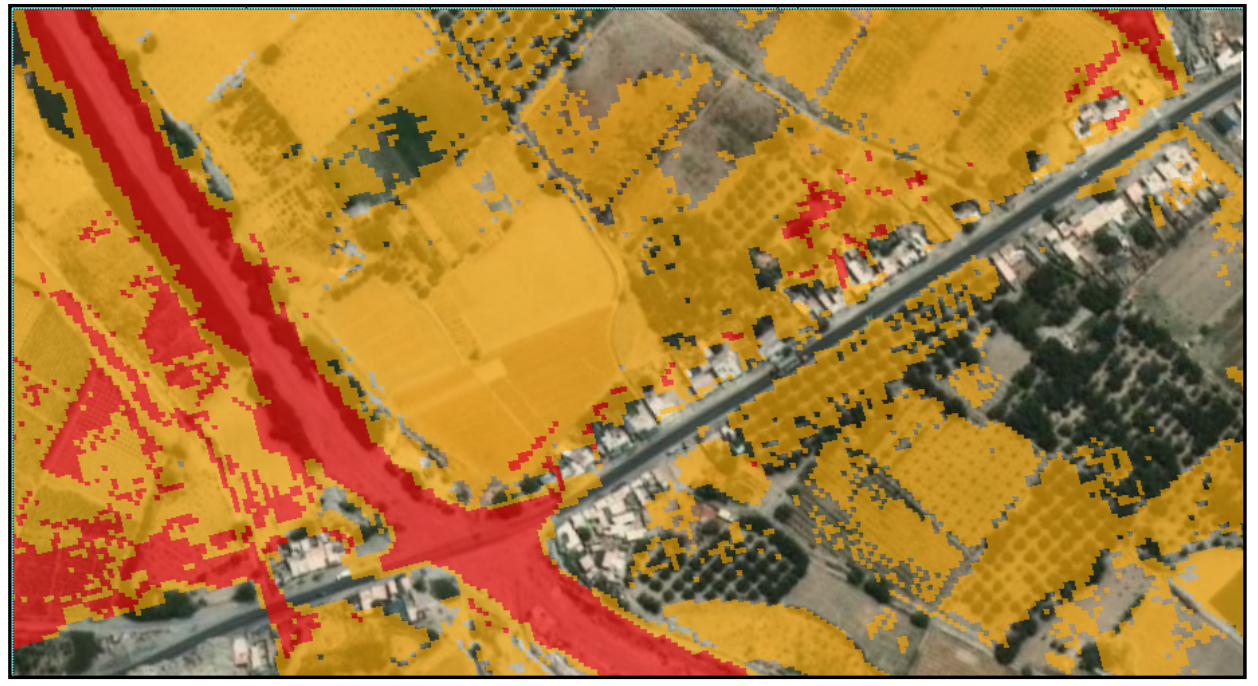

Figure 7: Hazard map in the Pescadores urban area for a 200-year return period.

Fig. 7 shows the hazard map in the case a mud avenue occurs in the Pescadores Valley. This map will allow the local administration a better planning in urban development and zoning.

\subsection{Mud flooding}

After the calibration was performed, a flood simulation of the valley and Panamericana highway was conducted. Those simulations were made for different return periods. This paper presents the one for 200 years [14].

Following the simulation, different solution alternatives were simulated and it was found that the best one is to build a bridge of $105 \mathrm{~m}$ in length at the junction of the Pescadores 
ravine with the Panamericana Sur Highway, as well as the channeling of the valley by means of earth dams and embedded to protect the crops and the Pescadores Valley; these being the most economical, viable and efficient measures.

Fig. 8 displays the comparison between the simulation of a mud avenue for a 200 -year return period and the simulation with the proposed solutions (channeling and bridge). In order for an eventual mud flow does not interrupt the transit of the Panamericana Sur Highway.

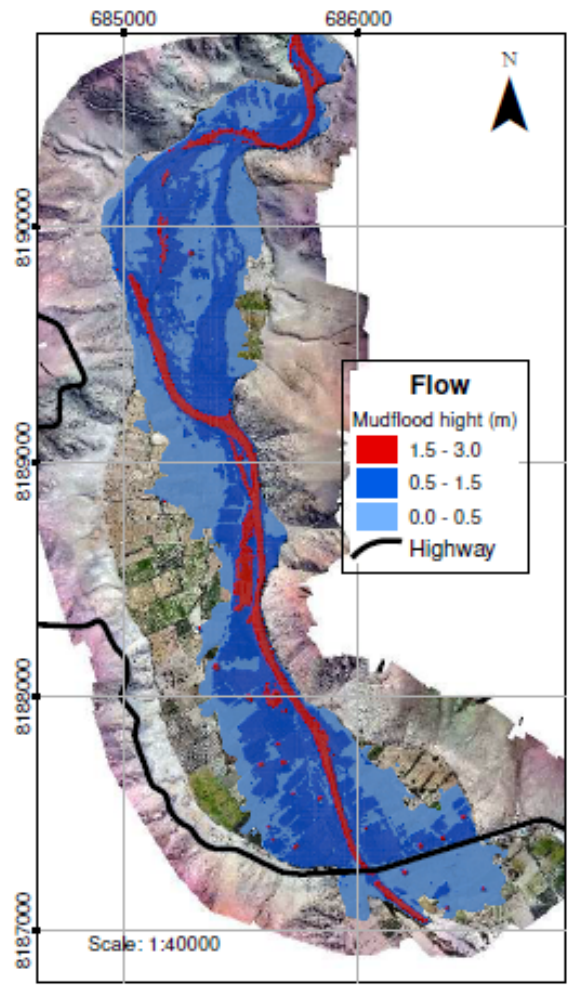

(a)

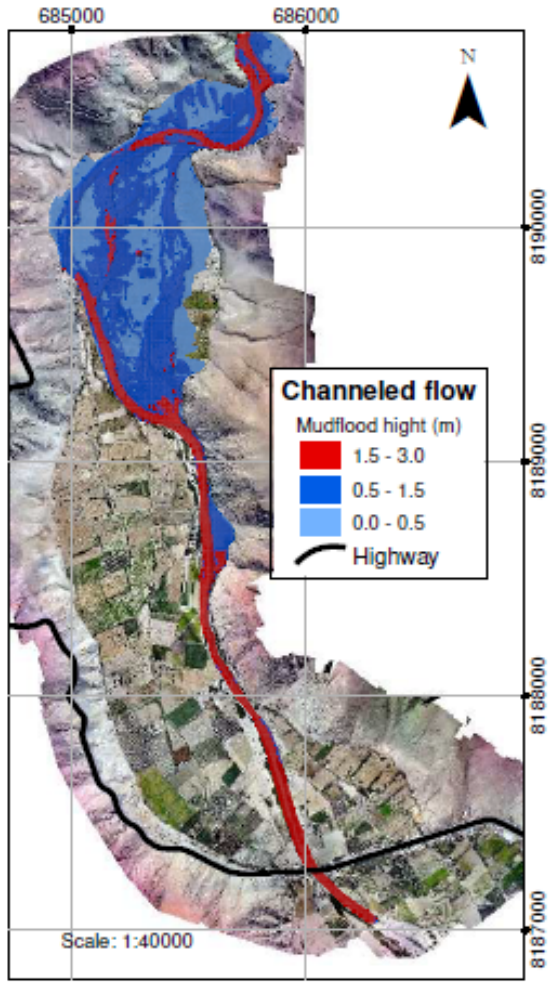

(b)

Figure 8: Depth resulting from the simulation of mud flooding, for a return period of 200 years. (a) No proposed solution; and (b) With proposed solution (bridge and embankment).

The left side of the Fig. 8 presents the simulation without considering the suggested solutions. It can be seen that the mud floods the road and interrupts vehicular traffic and affects the surrounding crops. The right side shows the simulation with the suggested solutions, which as we can see, does not interrupt vehicular traffic.

\subsection{Bridge and embankment}

The proposed solution considers the construction of a beam-type bridge with a total length of $105 \mathrm{~m}$ and a width of $12 \mathrm{~m}$. The channeling must be carried out by means of earthen and embedded dikes, which has a crown width and height of $4.00 \mathrm{~m}$ with an average height of $3.0 \mathrm{~m}$. Fig. 9 displays the proposed solutions. 


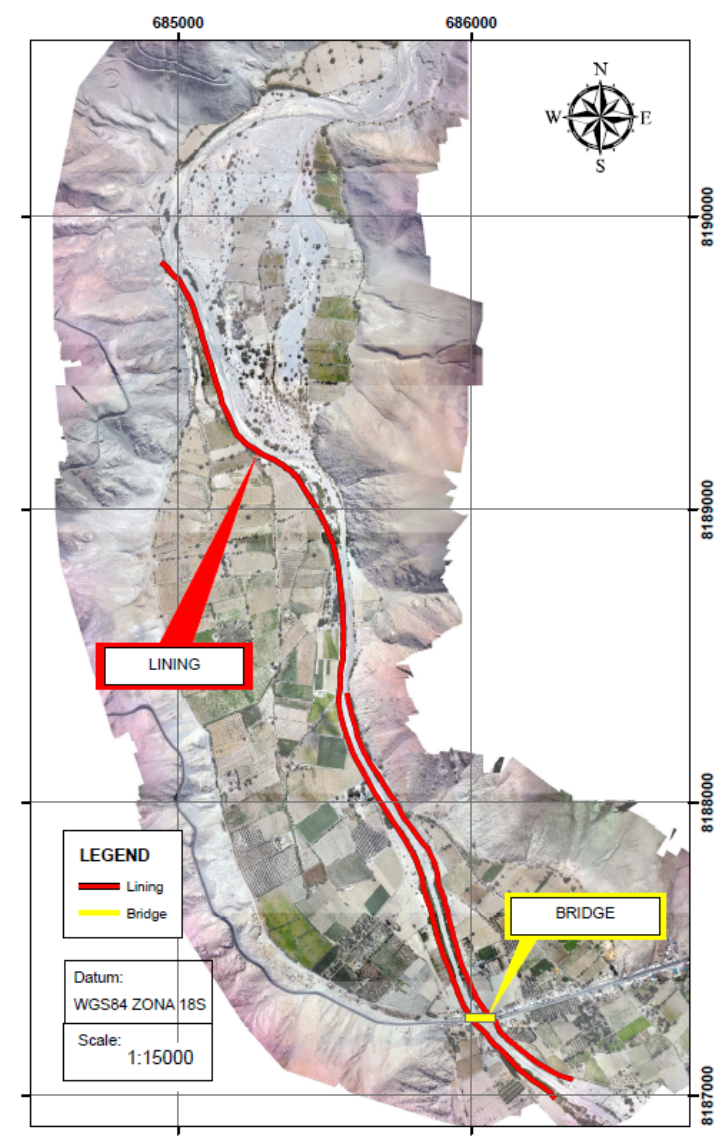

Figure 9: Proposal for the land, embankment solution and the construction of the Pescadores bridge.

\section{CONCLUSIONS AND RECOMMENDATIONS}

From in situ data it was found that the sediment-water concentration was 0.35 , which is classified as a "mud avenue"; from those conditions the simulation was conducted. A suitable solution given the conditions described above would be to channel the flow with earth and rock dikes.

When implementing the proposed solution to the simulation it was verified that the flow would no longer cause floods in the Pescadores valley and would not interrupt traffic in the Panamericana Highway.

Mud flooding simulations need a plethora of in situ information, such as topography, hydrology, soil mechanics, rheological parameters, the necessary knowledge of mathematical models that suit better to the phenomenon, and the numerical solution in order to be able to simulate and obtain optimal results.

It is recommended to install flow capacity stations in strategic points of the river since there is a lack of those. These stations would provide better tools when trying to calibrate simulation models. 
Additionally, it is advisable to use two-dimensional models of sludge flows since in its path there is a sludge cone. It would be better to use three-dimensional models; however, their formulations and solutions are almost impossible given their complexities. Future studies will begin to dig deeper into their solutions.

\section{REFERENCES}

[1] Macro consult, sistema de información. https://sim.macroconsult.pe/danos-de-el-ninous3-124-millones-hasta-ahora-macroconsult/. Accessed on: 2 Mar. 2019.

[2] Streeter, V.L., Wylie, F.B. \& Bedford, K.W., Fluid Mechanics, 9th ed., McGraw-Hill: Colombia, 2000.

[3] Castillo, N. \& Leonardo, F., Aplicación de un modelo numérico de flujo de escombros y lodo en una quebrada en el Peru., Universidad Nacional de Ingeniería, Lima, Peru, 2005.

[4] O'Brien, J., Julien, P. \& Fullerton, W.T., Two-dimensional water flood and mudflow simulation. Journal of Hydrologic Engineering, ASCE, 119(2), 1993. https://doi.org/10.1061/(ASCE)0733-9429(1993)119:2(244).

[5] O'Brien, J.S. \& Julien, P.Y., Physical processes of hyper concentrated sediment flows. Conference on the Delineation of Landslides, Floods and Debris Flow Hazards, Utah, USA, pp. 260-279, 1985.

[6] Bagnold, R.A., An empirical correlation of bedload transport rates in flume and materials rivers. Proceedings of the Royal Society of London, Series A Mathematical and Physical Sciences, 372(1751), pp. 453-473, 1980.

[7] IGN, Ficha Tecnica PCR-3, Peru, 2017.

[8] SENAMHI, Descarga de datos hidrometeorológicos, 9 Apr. 2017. www.senamhi.gob.pe/?p=descarga-datos-hidrometeorologicos.

[9] O'Brien, J.S. \& Julien, P.Y., Laboratory analysis of mudflow properties. Journal of Hydraulic Engineering, ASCE, 114(8), 1988. https://doi.org/10.1061/(ASCE)0733-9429(1988)114:8(877).

[10] PROVIAS, Ministerio de transportes y comunicaciones, Unidad zonal XIV, Arequipa, Report 13, 2012.

[11] Castillo, A., www.youtube.com/watch?v=Wd2xFrrTdSA. Accessed on: 12 Jan. 2018.

[12] Zegarra, H., Pasando el huayco por Pescadores panamericana sur. www.youtube.com/watch?v=2BEhPxUlpO8. Accessed on: 15 Mar. 2019.

[13] Garcia, R., Lopez, J., Noya, M., Bello, M., Gonzalez, N., Paredes, G. \& Vivas, M., Mapas de riesgo para eventos de flujo de barro y detritos en el estado de Vargas y Caracas. Informe proyecto Ávila: Caracas, Venezuela, 2002.

[14] Perez, A.V., Perez, N. \& Perez, A., Flooding simulation and channeling in the valley of the Andes mountain in the south Peru. WIT Transactions on Ecology and the Environmental, vol. 239, WIT Press: Southampton and Boston, pp. 287-293, 2019. 